J. Dairy Sci. 95:2707-2717

http://dx.doi.org/10.3168/jds.2011-4714

(C) American Dairy Science Association ${ }^{\circledR}, 2012$.

\title{
Breed differences over time and heritability estimates for production and reproduction traits of dairy goats in the United States
}

\author{
T. B. García-Peniche, ${ }^{*}$ H. H. Montaldo, $\dagger^{1}$ M. Valencia-Posadas, $\ddagger$ G. R. Wiggans,§ S. M. Hubbard,§ \\ J. A. Torres-Vázquez,\# and L. Shepardll \\ *Campo Experimental "La Posta," Instituto Nacional de Investigaciones Forestales, Agrícolas y Pecuarias, Paso del Toro, Veracruz 94277, México \\ †Departamento de Genética y Bioestadística, Facultad de Medicina Veterinaria y Zootecnia, Universidad Nacional Autónoma de México, \\ Ciudad Universitaria, DF 04510, México \\ ‡División de Ciencias de la Vida, Campus Irapuato-Salamanca, Universidad de Guanajuato, Ex Hacienda El Copal, Irapuato, \\ Guanajuato 36500, México \\ §Animal Improvement Programs Laboratory, Agricultural Research Service, US Department of Agriculture, Beltsville, MD 20705-2350 \\ \#Centro Nacional de Investigación en Fisiología y Mejoramiento Animal, Instituto Nacional de Investigaciones Forestales, Agrícolas y Pecuarias, \\ Ajuchitlán, Querétaro 76280, México \\ \|American Dairy Goat Association, Spindale, NC 28160
}

\begin{abstract}
To aid in improvement of breeding programs for production and reproduction traits of US dairy goats, breed differences over time were documented and genetic parameters were estimated. Data were from herds with $\geq 2$ breeds (Alpine, LaMancha, Nubian, Oberhasli, Saanen, or Toggenburg), but only purebred data were analyzed. Three kidding periods were examined: 1976 through 1984, 1985 through 1994, and 1995 through 2005. Univariate repeatability mixed models were used to estimate least squares means by kidding periodbreed and genetic parameters for milk, fat, and protein yields, combined fat and protein yield, fat and protein percentages, protein:fat ratio, age at first kidding, and kidding interval. Trends across kidding periods were favorable for most yield traits for all breeds but generally unfavorable for reproduction traits. Saanens had the highest milk (1,063 to $1,125 \mathrm{~kg})$ and protein yields (31 to $33 \mathrm{~kg}$ ). Nubians had the highest fat yields (37 to 40 $\mathrm{kg}$ ) and lowest milk yields (791 to $851 \mathrm{~kg}$ ). Oberhaslis had the lowest fat (31 to $33 \mathrm{~kg}$ ) and protein (23 to 27 $\mathrm{kg}$ ) yields. Alpines had the largest increase in milk yield (7.4\%); Oberhaslis had the largest increase in protein $(17.4 \%)$ and combined fat and protein $(13.2 \%)$ yields. Combined fat and protein yield was higher for Nubians, Saanens, and Alpines (65 to $72 \mathrm{~kg}$ ) than for LaManchas, Toggenburgs, and Oberhaslis ( 53 to $67 \mathrm{~kg}$ ). Nubians had the highest fat (4.7 to $4.8 \%$ ) and protein (3.6 to $3.8 \%$ ) percentages. Only Nubians increased in fat percentage (2.1\%); protein percentage increased most for Toggenburgs (7.4\%) and Alpines (7.1\%). Protein:fat ratio was
\end{abstract}

Received July 9, 2011.

Accepted January 13, 2012.

${ }^{1}$ Corresponding author: montaldo@servidor.unam.mx highest for Toggenburgs (0.84 to 0.89 ) and lowest for Nubians (0.76 to 0.81), but Nubians had the largest increase in protein:fat ratio (6.6\%). Saanens were oldest at first kidding (509 to $589 \mathrm{~d}$ ), and Toggenburgs and LaManchas generally were youngest (435 to $545 \mathrm{~d}$ ); age at first kidding increased most for Alpines (21.8\%) and LaManchas (21.6\%). Kidding intervals generally were shorter for Oberhaslis, LaManchas, and Nubians (350 to $377 \mathrm{~d}$ ) than for Toggenburgs, Alpines, and Saanens (373 to 387 d). Kidding interval increased most for $\mathrm{Nu}-$ bians $(3.9 \%)$ and Saanens $(3.8 \%)$ and decreased only for Oberhaslis (5.4\%). Heritability estimates across breeds were 0.35 for milk and fat yields, 0.37 for protein yield and protein:fat ratio, 0.36 for combined fat and protein yield, 0.52 for fat percentage, 0.54 for protein percentage, 0.23 for age at first kidding, and 0.05 for kidding interval. Genetic selection within breed is feasible for production and reproduction traits of US dairy goats. Key words: dairy goat breed, yield, reproduction, heritability

\section{INTRODUCTION}

Breeds are important potential sources of variation for genetic improvement and conservation of genetic diversity within species (Shrestha, 2005). Comprehensive studies of differences among dairy goat breeds for production and reproduction traits in goats are limited and based on small sample sizes or use experimental designs that are not suitable for statistical inference (Serradilla, 2001; Montaldo et al., 2010a). For US dairy goats, most studies (e.g., Wiggans et al., 1988; Wiggans, 1989; Majid et al., 1994) have focused on milk traits. Only a few (Majid et al., 1993) examined reproduction traits.

Goat breed has been found to affect milk production (e.g., Montaldo et al., 1995) and composition (e.g., 
Jenness, 1980; Raynal-Ljutovac et al., 2008) as well as cheese quality and yield (e.g., Pizzillo et al., 1994; Soryal et al., 2005). Studies on breed differences for the content of useful solids in milk (fat plus protein) or the ratio of protein to fat are not available for US dairy goats. However, the protein:fat ratio in milk might be important in determining cheese yield and quality because high values for protein:fat ratio are associated with increased cheese yield and improved cheese quality (Guinee et al., 2007).

Genetic evaluation of yield traits across breeds in the United States (Wiggans and Hubbard, 2001) uses breed-specific grouping of unknown parents. Although that grouping allows estimation of genetic differences among breeds for the base populations, it does not necessarily represent current differences among breeds or different genetic trends for economically important traits (Animal Improvement Programs Laboratory, 2011). Moreover, those estimates are not specifically designed to estimate breed differences from field data. Other estimates of differences among dairy goat breeds were based on a small number of records from only 1 experimental herd in the southern United States and were inconsistent (Majid et al., 1993, 1994). To provide unbiased and accurate breed comparison, data should be connected across herds (Swan and Kinghorn, 1992; Montaldo et al., 2010a). Furthermore, no studies have been conducted specifically to determine how yield performance of different US dairy goat breeds has changed over time.

Selection supported by yield evaluations produced with an animal model and across-breed analysis (Wiggans and Hubbard, 2001) has improved performance for most US dairy goat breeds. However, the impact of genetic evaluations on the genetic improvement of the overall population has been limited because of the small number of animals under selection (Haenlein, 1996; Montaldo and Manfredi, 2002). Genetic trends released by the US Department of Agriculture (USDA; Animal Improvement Programs Laboratory, 2011) included only 2,134 dairy goats born in 2008, with Alpines the most numerous (592 animals) and Oberhaslis the least numerous (98 animals). In addition, heritability estimates for several economically important traits of US dairy goats are old or unavailable (Iloeje et al., 1981; Kennedy et al., 1982; Montaldo et al., 2010b). Reliable genetic parameters for traits such as age at first kidding and protein:fat ratio also are unavailable for US dairy goats.

Most estimates of genetic parameters for dairy goats are available only for Mediterranean and Latin American countries (e.g., Barillet, 2007; Torres-Vázquez et al., 2009; Montaldo et al., 2010a). Genetic parameters for yield traits of dairy goats have been estimated for a few other goat populations (e.g., Muller et al., 2002; Morris et al., 2006; Andonov et al., 2007), but heritability estimates for other traits are limited (e.g., Kennedy et al., 1982; Bagnicka et al., 2007; Rupp et al., 2011).

Knowledge of breed characteristics and genetic parameters for economically important traits are major factors in improvement of productivity and development of breeding programs as well as in identification of genetic resources available for goat breeding worldwide. The objective of this study was to estimate breed differences for production and reproduction traits of US dairy goats across time. To assess the possibility of within-breed selection for those traits, the heritability of each trait was investigated across and within breed.

\section{MATERIALS AND METHODS}

\section{Data}

Nine traits were analyzed: milk, fat, and protein yields; combined fat and protein yield; fat and protein percentages; protein:fat ratio; age at first kidding; and kidding interval. Data were obtained from DHI lactation records that had been provided to the American Dairy Goat Association (Spindale, NC) from the USDA national dairy database (Beltsville, MD). Individual records for purebred registered Alpine, LaMancha, Nubian, Oberhasli, Saanen, and Toggenburg does included 305-d mature-equivalent milk, fat, and protein yields for kiddings from 1976 to 2005. Yields had been adjusted to mature equivalence for kidding age and season (yield expected from a doe kidding from January through March at 36 mo of age) within breed by the USDA but not for kidding interval (Wiggans, 1984). Three kidding periods were considered: 1976 to 1984, 1985 to 1994 , and 1995 to 2005. Records also included sire, dam, and herd identification, birth and kidding dates, parity status, and DIM. Records with $<100$ DIM were excluded as were records from parities after the sixth. Only herds with $\geq 100$ records, $\geq 2$ breeds, and $\geq 5$ records per breed were included from 1976 through 2005 . Herds were required to have $\geq 2$ breeds so that breeds could be compared in the same environment, thereby eliminating the possibility that differential environments by breed would affect breed comparison. Sires were required to have $\geq 10$ daughter records. Within breed, yield records that were $\geq 3$ standard deviations from the mean were designated as missing. Kidding intervals of $<170 \mathrm{~d}(\mathrm{n}=12)$ or $>730$ $d(n=112)$ and ages at first kidding of $<300 d(n=79)$ or $>1,095 \mathrm{~d}(\mathrm{n}=175)$ were also designated as missing. After data edits, 4,282 herd-year classes were available 
Table 1. Numbers of records used to analyze production and reproduction traits of US dairy goats by breed and kidding period

\begin{tabular}{|c|c|c|c|c|c|}
\hline Breed & $\begin{array}{l}\text { Kidding } \\
\text { period }\end{array}$ & $\begin{array}{l}\text { Milk yield, } \\
\text { fat yield, and } \\
\text { fat percentage }\end{array}$ & $\begin{array}{l}\text { Protein yield, } \\
\text { combined fat } \\
\text { and protein yield, } \\
\text { protein percentage, } \\
\text { and protein:fat ratio }\end{array}$ & $\begin{array}{c}\text { Age at } \\
\text { first kidding }\end{array}$ & $\begin{array}{l}\text { Kidding } \\
\text { interval }\end{array}$ \\
\hline \multirow[t]{3}{*}{ Alpine } & 1976-1984 & 6,912 & 1,944 & 2,712 & 3,016 \\
\hline & $1985-1994$ & 11,140 & 10,260 & 4,173 & 5,439 \\
\hline & $1995-2005$ & 9,981 & 9,970 & 3,334 & 5,723 \\
\hline \multirow{3}{*}{ LaMancha } & $1976-1984$ & 1.577 & 405 & 690 & 618 \\
\hline & 1985-1994 & 4,225 & 3,601 & 1,707 & 1,912 \\
\hline & $1995-2005$ & 3.664 & 3,653 & 1,218 & 2,084 \\
\hline \multirow[t]{3}{*}{ Nubian } & $1976-1984$ & 3,638 & 1,277 & 1,545 & 1,433 \\
\hline & $1985-1994$ & 6,830 & 6,067 & 2,687 & 3,232 \\
\hline & $1995-2005$ & 3,616 & 3,603 & 1,280 & 1,886 \\
\hline \multirow[t]{3}{*}{ Oberhasli } & $1981-1984$ & 78 & 10 & 41 & 29 \\
\hline & $1985-1994$ & 508 & 460 & 219 & 189 \\
\hline & $1995-2005$ & 545 & 543 & 209 & 262 \\
\hline \multirow[t]{3}{*}{ Saanen } & $1976-1984$ & 1,964 & 586 & 724 & 844 \\
\hline & $1985-1994$ & 3,906 & 3,493 & 1,456 & 1,868 \\
\hline & $1995-2005$ & 5,593 & 5,588 & 2,137 & 2,874 \\
\hline \multirow[t]{3}{*}{ Toggenburg } & $1976-1984$ & 3,037 & 818 & 1,127 & 1,329 \\
\hline & 1985-1994 & 4,258 & 3,700 & 1,522 & 2,093 \\
\hline & $1995-2005$ & 2.782 & 2.769 & 855 & 1,537 \\
\hline \multirow[t]{4}{*}{ All breeds } & $1976-1984$ & 17,206 & 5,041 & 6,839 & 7,269 \\
\hline & $1985-1994$ & 30.867 & 27,581 & 11.764 & 14.733 \\
\hline & $1995-2005$ & 26,181 & 26,126 & 9,033 & 14,366 \\
\hline & All periods & 74.254 & 58.748 & 27.636 & 36.368 \\
\hline
\end{tabular}

for analysis, with a mean of 17.7 records per class and a range of 1 to 522 records per class.

The numbers of records used for analysis are shown in Table 1 by breed, kidding period, and trait. The overall number of lactation records (Table 1) increased from 17,207 for 1976 to 1984 kiddings to 30,867 for 1985 to 1994 kiddings and then decreased to 26,181 for 1995 to 2005 kiddings. Saanen and Oberhasli were the only breeds to increase overall number of records with each kidding period. All records $(74,254)$ included milk and fat yields and fat percentage for all breeds. Protein information was available for only $29.3 \%$ of records for 1976 to 1984 kiddings, but $99.8 \%$ of records for 1995 to 2005 kiddings had protein data. Age at first kidding and kidding interval had the fewest records overall.

A pedigree file for 52,795 animals also was used for analysis. The total numbers of sires with progeny in the data set were 1,868 Alpines, 905 LaManchas, 1,637 Nubians, 165 Oberhaslis, 978 Saanens, and 908 Toggenburgs. The mean number of daughters per sire was 6.8 for Alpines, 5.0 for LaManchas, 4.3 for Nubians, 3.6 for Oberhaslis, 5.6 for Saanens, and 5.2 for Toggenburgs. The mean number of herd-years per sire was 6.8 for Alpines, 5.5 for LaManchas, 4.4 for Nubians, 4.1 for Oberhaslis, 5.6 for Saanens, and 5.8 for Toggenburgs. Most US dairy goats are bred using natural service; only about $3 \%$ of American Dairy Goat Association registrations during the last $10 \mathrm{yr}$ were for animals from AI matings (L. Shepard, unpublished data).

\section{Statistical Analysis}

Each trait was analyzed with a univariate repeatability animal model and ASReml software (Gilmour et al., 2006) to estimate variance components and fixed effects. The model was

$$
\mathbf{y}=\mathbf{X b}+\mathbf{Z a}+\mathbf{W m}+\mathbf{K h}+\mathbf{e}
$$

where $\mathbf{y}$ is a vector of record observations; $\mathbf{X}$ is an incidence matrix of fixed effects for kidding season, breed, kidding period, interaction between breed and kidding period, and parity $(1,2,3,4$, and $\geq 5)$; $\mathbf{b}$ is a vector of the fixed effects; $\mathbf{Z}$ is an incidence matrix for animal additive genetic effects; $\mathbf{a}$ is a vector of random animal additive genetic effects; $\mathbf{W}$ is an incidence matrix for permanent environmental effects; $\mathbf{m}$ is a vector of random permanent environmental effects; $\mathbf{K}$ is an incidence matrix for random herd-year effects nested in time period; $\mathbf{h}$ is a vector of random herd-year effects nested in time period; and $\mathbf{e}$ is a vector of random residual effects. To avoid losing data because some months did not have $\geq 5$ records per breed, 5 kidding seasons were defined so that seasons would have similar 
Table 2. Means, standard deviations, and coefficients of variation for production and reproduction traits of US dairy goats that kidded between 1976 and 2005 by breed

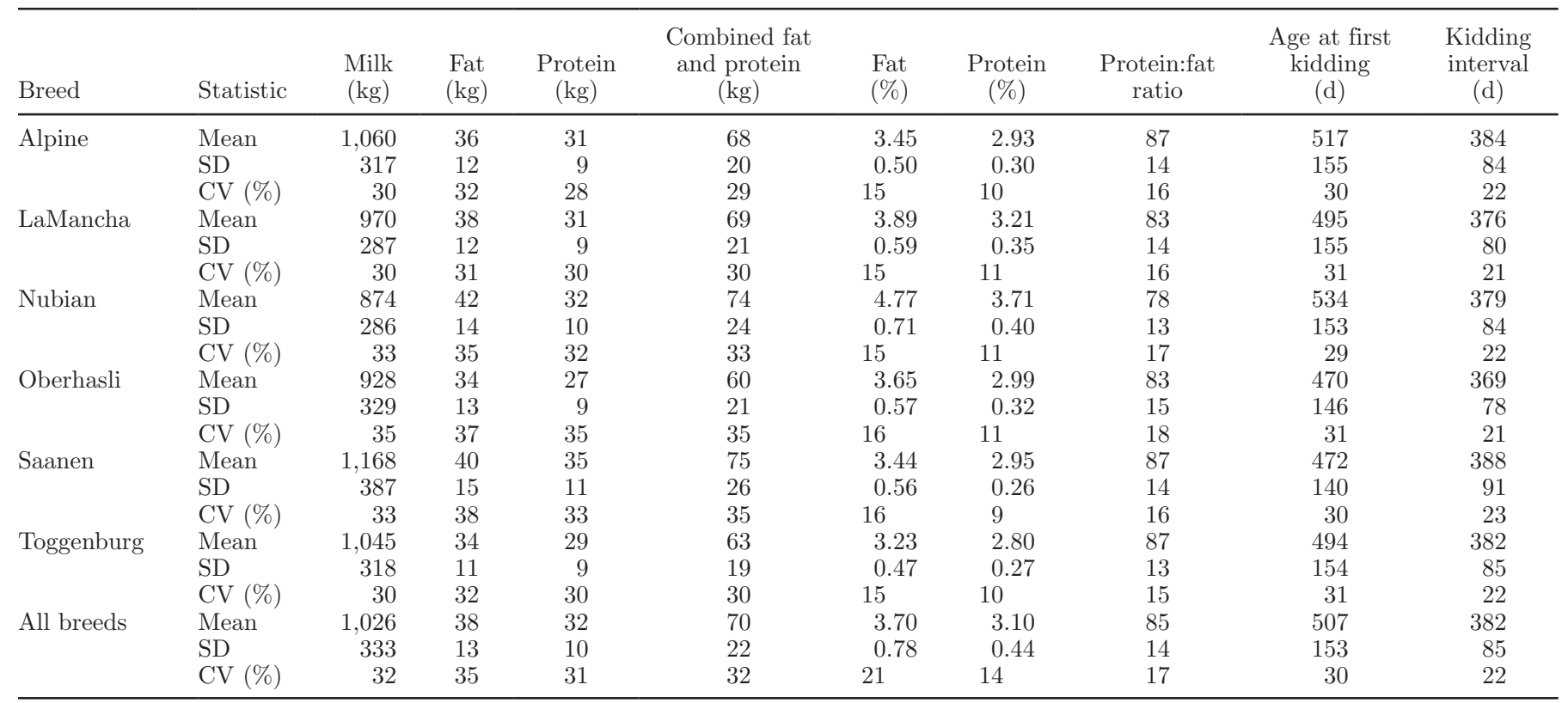

numbers of records based on the observed distribution of kiddings throughout the year for all breeds: June to December, January, February, March, and April to May. For age at first kidding, birth herd-year and birth season were used in the model instead of kidding herdyear and kidding season, respectively.

Heritability was estimated as $\hat{\sigma}_{a}^{2} / \hat{\sigma}_{p}^{2}$, where $\hat{\sigma}_{a}^{2}$ is estimated animal (additive genetic) variance and $\hat{\sigma}_{p}^{2}$ is estimated phenotypic variance. Repeatability was estimated as $\left(\hat{\sigma}_{a}^{2}+\hat{\sigma}_{m}^{2}\right) / \hat{\sigma}_{p}^{2}$, where $\hat{\sigma}_{m}^{2}$ is estimated permanent environmental variance. Also, $\hat{\sigma}_{p}^{2}=\hat{\sigma}_{a}^{2}+\hat{\sigma}_{m}^{2}+\hat{\sigma}_{e}^{2}$, where $\hat{\sigma}_{e}^{2}$ is estimated residual (temporary environmental) variance.

\section{RESULTS AND DISCUSSION}

Means, standard deviations, and coefficients of variation across and within breeds are shown in Table 2. Across breeds, mean yields (breed ranges within parentheses) were 1,026 (874 to 1,168$) \mathrm{kg}$ for milk, 38 (34 to 42 ) $\mathrm{kg}$ for fat, and 32 (27 to 35 ) $\mathrm{kg}$ for protein, with mean component percentages of 3.70 (3.23 to 4.77) for fat and 3.10 (2.80 to 3.71) for protein. Mean age at first kidding was 507 (470 to 534) d, and mean kidding interval was 382 (369 to 388) d. For production traits, coefficients of variation were lowest for component percentages and protein:fat ratio (14 to $21 \%$ across breeds and 9 to $18 \%$ within breed) and highest for yield traits (31 to $35 \%$ across breeds and 28 to $38 \%$ within breed).
Across breeds, the coefficient of variation (breed range within parentheses) was 30\% (29 to 31\%) for age at first kidding and $22 \%$ (21 to $23 \%$ ) for kidding interval.

Effects of breed and parity were highly significant $(P<0.01)$ for all traits. Effect of kidding period was significant $(P<0.01)$ for all traits except fat yield, and season effect was significant $(P<0.01)$ for all traits except kidding interval. The interaction between breed and time period was nonsignificant $(P \geq 0.05)$ for protein:fat ratio but significant $(P<0.05)$ for age at first kidding and highly significant $(P<0.01)$ for all other traits.

\section{Time Trends}

A trend for increased production was observed across kidding periods from $1976-1984$ to $1995-2005$ (from 1981-1984 to 1995-2005 for Oberhaslis) for milk, fat, and protein yields of most breeds based on least squares means (Table 3). However, Toggenburg production decreased by $15 \mathrm{~kg}$ of milk and $1 \mathrm{~kg}$ of fat from 1976-1984 to 1995-2005. The Animal Improvement Programs Laboratory (2011) reported that the genetic merit of Toggenburgs has decreased since a high for milk and protein yields in 1993 and fat yield in 1982, but genetic merit for yield traits has increased since the late 1970s for other breeds. The increase per kidding period from 1976-1984 to 1995-2005 (from 1981-1984 to $1995-2005$ for Oberhaslis) ranged from 31 to $74 \mathrm{~kg}$ for milk (excluding Toggenburgs), 2 to $3 \mathrm{~kg}$ for fat (ex- 
cluding Toggenburgs), 2 to $4 \mathrm{~kg}$ for protein, 3 to $7 \mathrm{~kg}$ for combined fat and protein yield, 0.1 to 0.2 for protein percentage, and 0.04 to 0.05 for protein:fat ratio. Fat percentage generally did not change over time.

Trends for reproduction traits based on least squares means by kidding period generally were unfavorable (Table 3). Age at first kidding increased over time for all breeds; the increase per kidding period from 19761984 to $1995-2005$ (from 1981-1984 to 1995-2005 for Oberhaslis) ranged from 76 to 104 d. Kidding interval increased 4 to $14 \mathrm{~d}$ for all breeds except Oberhasli (decrease of $20 \mathrm{~d}$ ). However, from 1985-1994 to 1995-2005, the kidding interval increased only for Saanens $(7 \mathrm{~d})$ and Toggenburgs (2 d), stayed the same for Alpines, and decreased for Nubians (1 d), LaManchas (4 d), and Oberhaslis $(27 \mathrm{~d})$.

The percentage change by breed across time periods (Table 4) was largest for age at first kidding (15.7 to $21.8 \%$ ), followed by protein yield (6.5 to $17.4 \%$ ) and combined fat and protein yield (5.0 to $13.2 \%)$. Less change was observed for fat yield ( -2.9 to $8.8 \%)$, milk yield ( -1.5 to $7.4 \%$ ), protein percentage (3.4 to $7.1 \%$ ), protein:fat ratio (4.8 to $6.6 \%)$, kidding interval ( -5.4 to $3.9 \%$ ), and fat percentage (0.0 to $2.1 \%$ ). Fat percentage was the most stable trait over time for each breed. The values in Table 4 represent the sum of genetic and environmental trends for each trait within breed and show that increases in yield traits generally were associated with increased age at first kidding and kidding interval. Those results are consistent with findings of positive (unfavorable) genetic and environmental correlations of first-parity milk yield with age at kidding (Kennedy et al., 1982) and kidding interval (Montaldo et al., 2010b).

\section{Breed Comparison}

As expected from previous studies in the United States (Grossman and Wiggans, 1980; Haenlein, 1981; Wiggans and Hubbard, 2001) and in other countries (Montaldo et al., 1995; Serradilla, 2001), high (Alpine, Saanen, and Toggenburg) and low (LaMancha, Nubian, and Oberhasli) breed groups were apparent. Milk yields were highest for Saanens (1,063 to 1,125 $\mathrm{kg}$ ) for all kidding periods (Table 3), followed closely by Alpines (1,006 to 1,080 kg) and Toggenburgs $(1,007$ to $1,038 \mathrm{~kg}$ ). However, the difference between Saanens and Toggenburgs increased over time. Alpines had the largest increase in milk yield $(7.4 \%)$ over the 3 kidding periods.

Although Nubians had the lowest milk yields (791 to $836 \mathrm{~kg}$ ) for all time periods, they had highest fat yields (37 to $41 \mathrm{~kg})$. Fat yields were only slightly less for Saanens (37 to $39 \mathrm{~kg}$ ) and Alpines (36 to $38 \mathrm{~kg}$ ). Oberhaslis

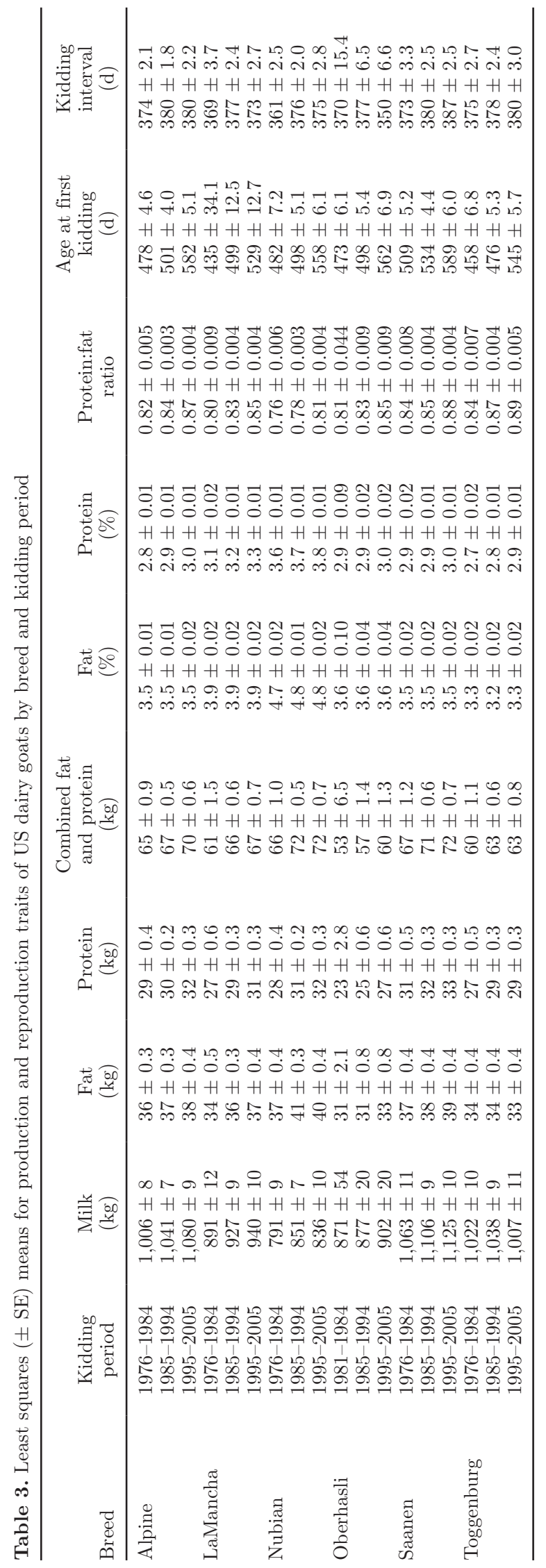

Journal of Dairy Science Vol. 95 No. 5, 2012 
Table 4. Change (\%) over kidding periods ${ }^{1}$ for production and reproduction traits of US dairy goats by breed

\begin{tabular}{|c|c|c|c|c|c|c|c|c|c|}
\hline Breed & $\begin{array}{l}\text { Milk } \\
\text { yield }\end{array}$ & $\begin{array}{l}\text { Fat } \\
\text { yield }\end{array}$ & $\begin{array}{c}\text { Protein } \\
\text { yield }\end{array}$ & $\begin{array}{l}\text { Combined } \\
\text { fat and } \\
\text { protein yield }\end{array}$ & $\begin{array}{c}\text { Fat } \\
\text { percentage }\end{array}$ & $\begin{array}{c}\text { Protein } \\
\text { percentage }\end{array}$ & $\begin{array}{l}\text { Protein:fat } \\
\text { ratio }\end{array}$ & $\begin{array}{l}\text { Age at first } \\
\text { kidding }\end{array}$ & $\begin{array}{l}\text { Kidding } \\
\text { interval }\end{array}$ \\
\hline Alpine & 7.4 & 5.6 & 10.3 & 7.7 & 0.0 & 7.1 & 6.1 & 21.8 & 1.6 \\
\hline Nubian & 5.7 & 8.1 & 14.3 & 9.1 & 2.1 & 5.6 & 6.6 & 15.8 & 3.9 \\
\hline Oberhasli & 3.6 & 6.5 & 17.4 & 13.2 & 0.0 & 3.4 & 4.9 & 18.8 & -5.4 \\
\hline Saanen & 5.8 & 5.4 & 6.5 & 7.5 & 0.0 & 3.4 & 4.8 & 15.7 & 3.8 \\
\hline Toggenburg & -1.5 & -2.9 & 7.4 & 5.0 & 0.0 & 7.4 & 6.0 & 19.0 & 1.3 \\
\hline
\end{tabular}

${ }^{1}$ From 1976-1984 to 1995-2005 for all breeds except Oberhasli, for which the beginning kidding period was 1981 to 1984.

had the lowest fat yields (31 to $33 \mathrm{~kg}$ ). Alpines had the largest increase in fat yield (8.8\%) across time. Haenlein (1981) reported fat yields and breed rankings that were similar to those for the 1976 to 1984 time period. Protein yields were highest for Saanens (31 to 33 $\mathrm{kg}$ ), followed closely by Alpines (29 to $32 \mathrm{~kg}$ ) and $\mathrm{Nu}-$ bians (28 to $32 \mathrm{~kg}$ ), and lowest for Oberhaslis (23 to 27 $\mathrm{kg}$ ). Combined component yields were highest for $\mathrm{Nu}-$ bians and Saanens and lowest for Oberhaslis. However, Oberhaslis had the largest increase in protein (17.4\%) and combined fat and protein $(13.2 \%)$ yields. The high combined fat and protein yields with less carrier should be an advantage for Nubian milk for manufacturing cheese and other milk-derived products, because liquid often needs to be eliminated and milk with more solids would be cheaper and more environmentally friendly to process. Soryal et al. (2005) reported higher cheese yield and less varied sensory scores for soft cheese from Nubian milk compared with Alpine milk and recommended the use of Nubians for producers that are interested in cheese markets (Zeng et al., 2007). Because Nubians produce approximately the same amount of combined fat and protein yield as Alpines or Saanens but have lower milk yields, they may adapt more easily to lactational metabolic demands and their period of postpartum negative energy balance may be shorter with possible benefits for health and reproduction.

Milk, fat, and protein yield for does (Table 3) for various kidding periods were expected to be similar to those reported in previous USDA studies, because data from those studies were combined and expanded for this study. Rankings of breeds for yield traits in Table 3 were similar to those reported by Wiggans et al. (1988), Wiggans (1989), and Wiggans and Hubbard (2001). Wiggans et al. (1988) reported means of 766 to $976 \mathrm{~kg}$ for milk yield and 31 to $35 \mathrm{~kg}$ for fat yield for does born between 1973 and 1986, which are lower than means in Table 3 for does that kidded between 1976 and 1984 .

Wiggans (1989) reported positive genetic trends for does born in 1984 for all yields traits of all breeds. Means in Table 3 for does that kidded between 1985 and 1994 generally were similar to those reported by Wiggans (1989) for does that were born in 1984. Wiggans and Hubbard (2001) reported small positive genetic trends for all yield traits for all breeds except Toggenburg, which had a small negative trend for milk yield and no trend for fat and protein yields. Mean yields for does that kidded between 1995 and 2005 (Table 3) generally were the same or slightly higher than those reported for does born in 1996 by Wiggans and Hubbard (2001) for all breeds except Nubian, which had lower means for all yield traits.

Nubians had the highest component percentages (4.7 to $4.8 \%$ for fat and 3.6 to $3.8 \%$ for protein) for all time periods (Table 3), which explains their similarity to Saanens and Alpines for component yields despite milk yield differences. Component percentages were lowest for Toggenburgs (3.2 to $3.3 \%$ for fat and 2.7 to $2.9 \%$ for protein). Only Nubians increased in fat percentage $(2.1 \%)$ over time; protein percentage increased most for Toggenburgs (7.4\%) and Alpines (7.1\%; Table 4). Haenlein (1981) reported fat percentages and breed rankings that were similar to those for the 1976 to 1984 time period. Maga et al. (2009) estimated that the frequency for the $\alpha_{s 1}-C N$ gene's $\mathrm{A}$ and $\mathrm{B}$ alleles, which have a strong favorable effect on the rate of protein synthesis, was 0.88 for Nubians, 0.67 for LaManchas, 0.25 for Oberhaslis, 0.18 for Alpines, 0.03 for Toggenburgs, and 0.00 for Saanens. The similarity in their ranking of US breeds for strong $\alpha_{s 1}-C N$ allele frequency and the ranking for protein percentage in Table 3 suggests a strong genetic relationship between $\alpha_{s 1} C N$ and protein percentage. However, those strong $\alpha_{s 1}-C N$ alleles could also be indicators of low genetic merit for milk yield, because the breed rankings in Table 3 for fat and protein percentages are almost identical and inversely related to the breed rankings for milk yield. Moreover, many genes likely control fat and protein percentages and yield traits in goats (Barillet, 2007).

The protein:fat ratio (Table 3) was highest for Toggenburgs (0.84 to 0.89), followed by Saanens (0.84 to 0.88 ) and lowest for Nubians (0.76 to 0.81 ). However, 
Nubians had the largest increase in protein:fat ratio over time $(6.6 \%)$.

The age at first kidding (Table 3) was highest for Saanens (509 to $589 \mathrm{~d}$ ) and lowest for LaManchas (435 to $529 \mathrm{~d}$ ). The age at first kidding also increased most for Alpines (21.8\%) and LaManchas (21.6\%). Galina et al. (1995) and Silva et al. (1998) both reported a mean age at first kidding of $427 \mathrm{~d}$ for Mexican dairy goats on farms in central Mexico, which was lower than found for any breed in this study. The lower age at first kidding may have resulted from less reproductive seasonality in central Mexico, continuous breeding, and the possible presence of local goat genes in the population. Bagnicka et al. (2007) also reported lower age at first kidding for Polish dairy goats $(417 \mathrm{~d})$, which are primarily of Alpine and Saanen ancestry, and for Norwegian dairy goats $(409 \mathrm{~d})$. The mean age at first kidding was $420 \mathrm{~d}$ for Alpines and $416 \mathrm{~d}$ for Saanens in France under intensive growing systems with seasonal breeding and estrus synchronization (Boichard et al., 1989). The higher ages at first kidding in the United States may be related primarily to management issues that include nutrition of young replacement females and strict seasonal reproduction.

Saanens, Alpines, and Toggenburgs had longer kidding intervals ( 373 to $387 \mathrm{~d}$ ), and Oberhaslis, Nubians, and LaManchas had shorter kidding intervals (350 to 377 d; Table 3). Kidding interval increased most over time for Nubians (3.9\%) and Saanens (3.8\%); kidding interval decreased only for Oberhaslis (5.4\%). Montaldo et al. (1981) found shorter kidding intervals for highgrade Mexican Nubians (352 d), Alpines (377 d), and Toggenburgs $(376 \mathrm{~d})$ than for Saanens $(430 \mathrm{~d})$ under intensive management and using small sample sizes for each breed. The shorter kidding intervals for Nubians may be related to less breeding seasonality compared with the other breeds, which may be expressed as better reproductive performance under management in an environment with less variation in day length (Montaldo et al., 2010a). Bagnicka et al. (2007) reported kidding intervals of $359.0 \mathrm{~d}$ for Polish and $375.8 \mathrm{~d}$ for Norwegian dairy goats.

Breed rankings for each yield trait generally were consistent across time (Table 3), especially for higher and lower rankings. Breed rankings for reproductive traits varied more over time but still were fairly consistent. Similarly, differences between highest and lowest breeds also generally were stable across time for yield traits but showed more variation for reproductive traits. That difference was largest for 1976 to 1984 kiddings for age at first kidding and for 1995 to 2005 kiddings for kidding interval.

\section{Genetic Parameters}

Heritability and repeatability estimates across and within breeds and associated phenotypic standard deviations are shown in Table 5. The small standard errors for estimated heritability (close to 0.01) and repeatability (0.004 to 0.006) for across-breed analysis resulted from the large size of the data set. Component percentages had the highest estimated heritabilities (0.54 for protein and 0.52 for fat), followed by yield traits ( 0.37 for protein and protein:fat ratio, 0.36 for combined fat and protein, and 0.35 for milk and fat). Those heritability estimates suggest that selection to improve milk quality directly should be successful. As expected, estimated repeatability was largest for component percentages (0.63 for protein and 0.60 for fat). For yield traits, estimated repeatabilities were 0.14 to 0.16 more than their corresponding estimated heritabilities ( 0.51 for milk, 0.49 for fat, 0.52 for protein, 0.50 for combined fat and protein, and 0.46 for protein:fat ratio).

For yield traits, estimated heritabilities within breed (Table 5) were similar to across-breed estimates for Alpines and Saanens (0.34 to 0.38) but were somewhat higher for LaManchas, Nubians, and Toggenburgs (0.40 to 0.50 ) and much higher for Oberhaslis (0.59 to 0.61 ). Estimated heritabilities within breed for fat percentage were similar to the across-breed estimate for Alpines and LaManchas (0.50 to 0.51), slightly higher for $\mathrm{Nu}$ bians and Toggenburgs (0.56 to 0.59), and slightly lower for Oberhaslis and Saanens (0.42 to 0.46); for protein percentage, estimated within-breed heritabilities were higher than the across-breed estimate for LaManchas, Nubians, and Toggenburgs (0.57 to 0.66) and lower for Alpines, Oberhaslis, and Saanens (0.43 to 0.46). Oberhasli heritability estimates likely were overestimated because of confounding of sire and herd-year effects as a result of the small number of sires (165) and small mean number of daughters per sire (3.6) and herd-years per sire (4.1). Because $97 \%$ of the matings were natural service and number of herd-years per sire was small for all breeds (4.1 to 6.8), breeds other than Oberhasli also may have similar confounding and inflated heritability estimates.

Heritability estimates from this study were higher for some breeds than the range considered to be typical for yield traits $(\sim 0.30)$ for sheep and goats (Barillet, 2007) but within that range for component percentages ( $\sim 0.50$ to 0.60$)$. The across-breed and Alpine and Saanen heritability estimates for milk, fat, and protein yields (0.34 to 0.38 ) were similar to those reported by Bélichon et al. (1999) for Alpine (0.34 to 0.37) and 
Table 5. Heritabilities, repeatabilities, herd-year proportions of total variance ( \pm SE), and phenotypic standard deviations ${ }^{1}$ for production and reproduction traits of US dairy goats by breed

\begin{tabular}{|c|c|c|c|c|c|c|c|c|c|c|}
\hline Breed & Parameter & $\begin{array}{l}\text { Milk } \\
(\mathrm{kg})\end{array}$ & $\begin{array}{l}\text { Fat } \\
(\mathrm{kg})\end{array}$ & $\begin{array}{l}\text { Protein } \\
\quad(k g)\end{array}$ & $\begin{array}{l}\text { Combined fat } \\
\text { and protein }(\mathrm{kg})\end{array}$ & $\begin{array}{l}\text { Fat } \\
(\%)\end{array}$ & $\begin{array}{l}\text { Protein } \\
(\%)\end{array}$ & $\begin{array}{l}\text { Protein:fat } \\
\text { ratio }\end{array}$ & $\begin{array}{l}\text { Age at first } \\
\text { kidding (d) }\end{array}$ & $\begin{array}{c}\text { Kidding } \\
\text { interval (d) }\end{array}$ \\
\hline \multirow[t]{4}{*}{ Alpine } & Heritability & $0.36 \pm 0.02$ & $0.36 \pm 0.02$ & $0.36 \pm 0.02$ & $0.36 \pm 0.02$ & $0.51 \pm 0.02$ & $0.46 \pm 0.02$ & $0.36 \pm 0.02$ & $0.22 \pm 0.02$ & $0.06 \pm 0.01$ \\
\hline & Repeatability & $0.53 \pm 0.01$ & $0.52 \pm 0.01$ & $0.53 \pm 0.01$ & $0.53 \pm 0.01$ & $0.64 \pm 0.01$ & $0.65 \pm 0.01$ & $0.47 \pm 0.01$ & - & $0.06 \pm 0.01$ \\
\hline & Herd-year proportion & $0.23 \pm 0.01$ & $0.28 \pm 0.01$ & $0.28 \pm 0.01$ & $0.29 \pm 0.01$ & $0.19 \pm 0.01$ & $0.13 \pm 0.01$ & $0.18 \pm 0.01$ & $0.45 \pm 0.01$ & $0.09 \pm 0.01$ \\
\hline & Phenotypic SD & 268 & 10 & 7 & 17 & 0.45 & 0.27 & 12 & 119 & 80 \\
\hline \multirow{4}{*}{ LaMancha } & Heritability & $0.48 \pm 0.03$ & $0.43 \pm 0.03$ & $0.54 \pm 0.03$ & $0.50 \pm 0.03$ & $0.50 \pm 0.03$ & $0.66 \pm 0.03$ & $0.41 \pm 0.03$ & $0.28 \pm 0.05$ & $0.04 \pm 0.02$ \\
\hline & Repeatability & $0.61 \pm 0.01$ & $0.56 \pm 0.01$ & $0.64 \pm 0.01$ & $0.61 \pm 0.01$ & $0.59 \pm 0.01$ & $0.68 \pm 0.01$ & $0.51 \pm 0.02$ & - & $0.04 \pm 0.02$ \\
\hline & Herd-year proportion & $0.16 \pm 0.01$ & $0.22 \pm 0.01$ & $0.23 \pm 0.01$ & $0.21 \pm 0.01$ & $0.16 \pm 0.01$ & $0.12 \pm 0.01$ & $0.12 \pm 0.01$ & $0.40 \pm 0.02$ & $0.09 \pm 0.01$ \\
\hline & Phenotypic SD & 250 & 10 & 8 & 17 & 0.52 & 0.31 & 12 & 121 & 75 \\
\hline \multirow[t]{4}{*}{ Nubian } & Heritability & $0.44 \pm 0.02$ & $0.40 \pm 0.02$ & $0.45 \pm 0.03$ & $0.42 \pm 0.02$ & $0.56 \pm 0.02$ & $0.57 \pm 0.02$ & $0.29 \pm 0.02$ & $0.32 \pm 0.04$ & $0.02 \pm 0.01$ \\
\hline & Repeatability & $0.54 \pm 0.01$ & $0.50 \pm 0.01$ & $0.54 \pm 0.01$ & $0.51 \pm 0.01$ & $0.58 \pm 0.01$ & $0.63 \pm 0.01$ & $0.30 \pm 0.01$ & - & $0.02 \pm 0.01$ \\
\hline & Herd-year proportion & $0.23 \pm 0.01$ & $0.28 \pm 0.01$ & $0.30 \pm 0.01$ & $0.32 \pm 0.01$ & $0.17 \pm 0.01$ & $0.12 \pm 0.01$ & $0.24 \pm 0.01$ & $0.37 \pm 0.02$ & $0.12 \pm 0.01$ \\
\hline & Phenotypic SD & 229 & 11 & 8 & 18 & 0.50 & 0.36 & 11 & 122 & 77 \\
\hline \multirow[t]{4}{*}{ Oberhasli } & Heritability & $0.61 \pm 0.03$ & $0.60 \pm 0.03$ & $0.59 \pm 0.04$ & $0.59 \pm 0.04$ & $0.42 \pm 0.09$ & $0.46 \pm 0.09$ & $0.27 \pm 0.09$ & $0.61 \pm 0.14$ & $0.02 \pm 0.10$ \\
\hline & Repeatability & $0.61 \pm 0.03$ & $0.60 \pm 0.03$ & $0.59 \pm 0.04$ & $0.59 \pm 0.04$ & $0.60 \pm 0.03$ & $0.54 \pm 0.04$ & $0.31 \pm 0.05$ & - & $0.08 \pm 0.06$ \\
\hline & Herd-year proportion & $0.20 \pm 0.03$ & $0.18 \pm 0.03$ & $0.22 \pm 0.03$ & $0.20 \pm 0.03$ & $0.15 \pm 0.03$ & $0.14 \pm 0.03$ & $0.29 \pm 0.04$ & $0.53 \pm 0.06$ & $0.15 \pm 0.05$ \\
\hline & Phenotypic SD & $263^{2}$ & 11 & 8 & 18 & 0.50 & 0.29 & 12 & 105 & 70 \\
\hline \multirow[t]{4}{*}{ Saanen } & Heritability & $0.36 \pm 0.02$ & $0.34 \pm 0.02$ & $0.38 \pm 0.03$ & $0.37 \pm 0.03$ & $0.46 \pm 0.02$ & $0.43 \pm 0.03$ & $0.48 \pm 0.03$ & $0.16 \pm 0.04$ & $0.06 \pm 0.02$ \\
\hline & Repeatability & $0.51 \pm 0.01$ & $0.45 \pm 0.01$ & $0.51 \pm 0.01$ & $0.47 \pm 0.01$ & $0.59 \pm 0.01$ & $0.51 \pm 0.01$ & $0.57 \pm 0.01$ & & $0.06 \pm 0.02$ \\
\hline & Herd-year proportion & $0.24 \pm 0.01$ & $0.33 \pm 0.01$ & $0.29 \pm 0.01$ & $0.34 \pm 0.02$ & $0.15 \pm 0.01$ & $0.11 \pm 0.01$ & $0.13 \pm 0.01$ & $0.37 \pm 0.02$ & $0.21 \pm 0.02$ \\
\hline & Phenotypic SD & 307 & 11 & 9 & 19 & 0.49 & 0.24 & 13 & 114 & 77 \\
\hline \multirow[t]{4}{*}{ Toggenburg } & Heritability & $0.47 \pm 0.02$ & $0.44 \pm 0.03$ & $0.49 \pm 0.03$ & $0.47 \pm 0.03$ & $0.59 \pm 0.03$ & $0.57 \pm 0.03$ & $0.51 \pm 0.03$ & $0.32 \pm 0.05$ & $0.08 \pm 0.02$ \\
\hline & Repeatability & $0.56 \pm 0.01$ & $0.53 \pm 0.01$ & $0.58 \pm 0.01$ & $0.56 \pm 0.01$ & $0.61 \pm 0.01$ & $0.59 \pm 0.01$ & $0.58 \pm 0.01$ & - & $0.08 \pm 0.02$ \\
\hline & Herd-year proportion & $0.17 \pm 0.01$ & $0.24 \pm 0.01$ & $0.25 \pm 0.02$ & $0.25 \pm 0.02$ & $0.15 \pm 0.01$ & $0.21 \pm 0.01$ & $0.19 \pm 0.01$ & $0.45 \pm 0.02$ & $0.17 \pm 0.02$ \\
\hline & Phenotypic SD & 269 & 9 & 7 & 15 & 0.42 & 0.24 & 12 & & 76 \\
\hline \multirow[t]{4}{*}{ All breeds } & Heritability & $0.35 \pm 0.009$ & $0.35 \pm 0.009$ & $0.37 \pm 0.011$ & $0.36 \pm 0.011$ & $0.52 \pm 0.009$ & $0.54 \pm 0.011$ & $0.37 \pm 0.010$ & $0.23 \pm 0.015$ & $0.05 \pm 0.006$ \\
\hline & Repeatability & $0.51 \pm 0.004$ & $0.49 \pm 0.005$ & $0.52 \pm 0.005$ & $0.50 \pm 0.005$ & $0.60 \pm 0.004$ & $0.63 \pm 0.004$ & $0.46 \pm 0.005$ & - & $0.05 \pm 0.006$ \\
\hline & $\begin{array}{l}\text { Herd-year-breed } \\
\text { proportion }\end{array}$ & $0.23 \pm 0.009$ & $0.34 \pm 0.007$ & $0.34 \pm 0.007$ & $0.35 \pm 0.008$ & $0.18 \pm 0.005$ & $0.13 \pm 0.004$ & $0.20 \pm 0.006$ & $0.41 \pm 0.009$ & $0.12 \pm 0.005$ \\
\hline & Phenotypic SD & 261 & 10 & 7 & 17 & 0.50 & 0.29 & 12 & 119 & 80 \\
\hline
\end{tabular}

${ }^{1}$ Phenotypic $\mathrm{SD}=(\text { additive genetic }+ \text { permanent environment }+ \text { error variances })^{0.5}$

${ }^{2}$ Phenotypic SD $=$ (unadjusted variance minus herd-year variance estimate $)^{0.5}$ because the estimate of phenotypic variance was biased. 
Saanen (0.32 to 0.40) French populations using large data sets of primiparous goats and similar statistical methodology but with probably better-connected herdyears because of AI use. Heritability estimates of 0.29 to 0.39 for milk, fat and protein yields of French Alpine and Saanen primiparous goats by Boichard et al. (1989) and Rupp et al. (2011) were also similar to the estimates for US Alpines and Saanens. Ilahi et al. (1998) estimated a heritability of 0.32 and a repeatability of 0.53 for milk yield of French Alpines using a repeatability model. Morris et al. (2006) reported heritability estimates of 0.35 (repeatability of 0.52 ) for daily milk yield and 0.30 (repeatability of 0.47 ) for combined fat and protein yield of New Zealand Saanens. Heritability estimates of Kennedy et al. (1982) for milk and fat yields and fat percentage of US goats adjusted for kidding age-season were $0.68,0.61$, and 0.54 , respectively, for Alpines, Saanens, and Toggenburgs and 0.35 for milk yield and 0.54 for fat yield for Nubians. Montaldo et al. (2010b) estimated heritability for first-parity milk yield of US dairy goats as 0.36 across breeds and from 0.35 to 0.38 within breed.

Some other recent studies have reported lower heritabilities for yield traits and component percentages. Weppert and Hayes (2004) estimated heritabilities of 0.19 for milk yield, 0.21 for fat yield, and 0.17 for protein yield for first-lactation dairy goats in Quebec, Canada. Muller et al. (2002) reported heritability estimates of 0.23 for milk yield, 0.22 for fat yield, and 0.20 for protein yield of South African Saanens. For Saanens in central Mexico (Valencia et al., 2007; Torres-Vázquez et al., 2009, 2010), heritability estimates ranged from 0.17 to 0.30 for milk yield, 0.19 to 0.30 for fat yield, 0.17 to 0.19 for protein yield, 0.12 for combined fat and protein yield, 0.25 to 0.32 for fat percentage, and 0.29 to 0.38 for protein percentage. Rupp et al. (2011), estimated heritabilities of 0.60 to 0.67 for fat and protein contents of French Alpines and Saanens.

Estimates of heritability across, rather than within, breed may be more appropriate for genetic evaluation of yield traits for dairy goats in the United States. The across-breed evaluation used by the USDA for dairy goats is desirable because it allows animals from all breeds to serve as contemporaries in mixed-breed herds (Wiggans, 1989). A single heritability is most convenient in such a situation, although differences in heritability can be accommodated by adjusting observation variance. For US dairy cattle, the USDA accounts for the higher heritability of Jersey and Brown Swiss cows for yield traits by adjusting their lactation-length weights (VanRaden et al., 2007).

Repeatability estimates for yield traits in Table 5 were slightly higher than those reported in Mexican studies for yields (0.39 to 0.43; Valencia et al., 2007;
Torres-Vázquez, 2008; Torres-Vázquez et al., 2009) but generally similar for component percentages $(0.35$ to 0.64; Torres-Vázquez et al., 2009). Repeatability estimates for other traits are limited for dairy goats because most heritability studies (e.g., Boichard et al., 1989; Bélichon et al., 1999; Rupp et al., 2011) have included data only from primiparous goats.

For protein:fat ratio, Torres-Vázquez (2008) reported a heritability estimate of 0.33 for Mexican Saanens, which was similar to the heritability estimate of 0.37 in Table 5. Higher heritability estimates for protein:fat ratio (0.58 to 0.69 ) have been reported for cattle (e.g., de Jager and Kennedy, 1987; Meinert et al., 1989).

Estimated heritability for age at first kidding (Table 5) was 0.23 across breeds and from 0.16 to 0.32 within breed (excluding the estimate for Oberhaslis). TorresVázquez et al. (2009) estimated heritability of age at first kidding to be 0.31 for Mexican Saanens. For Polish dairy goats, Bagnicka et al. (2007) estimated heritability for age at first kidding as 0.13 . Heritability estimates of 0.01 to 0.74 have been reported for age at first calving for dairy cattle (Shanks et al., 1982; Ruiz-Sánchez et al., 2007). The wide range of heritability estimates for age at first calving in dairy cattle indicate that the heritability of that trait may be difficult to estimate because of confounding between sire and herd-year effects. For dairy goats under seasonal reproduction (such as in the United States), age at first kidding is a bimodal trait, with a second peak associated with goats that became pregnant during a second reproductive season.

Estimated heritability and repeatability across breeds for kidding interval (Table 5) were both 0.05 , which was the same as the heritability estimate reported previously for the US goat population using only first-kidding data (Montaldo et al., 2010b). Within breed, Montaldo et al. (2010b) estimated the heritability of kidding interval to range from 0.00 to 0.15 ; in Table 5 , the range was from 0.02 to 0.08 , which is similar to estimated heritabilities of 0.02 and 0.03 for Polish and Norwegian dairy goats, respectively (Bagnicka et al., 2007).

\section{CONCLUSIONS}

For all time periods, Alpines, Saanens, and Nubians had higher combined fat and protein yields compared with LaManchas, Oberhaslis, and Toggenburgs. Nubian milk composition (high combined fat and protein yield with less milk volume) indicates that this breed could be an important genetic resource when selecting animals for goat cheese production. Saanens were the oldest at first kidding, but all breeds had unfavorable (increasing) trends for age at first kidding across time. Nubians, LaManchas, and Oberhaslis had shorter kid- 
ding intervals compared with Alpines, Saanens, and Toggenburgs, which all had kidding intervals that increased slightly across time. Estimates of heritability and repeatability indicated that successful selection is feasible for all examined traits in all breeds. Because age at first kidding and kidding interval are easy to measure and heritable, those traits could be included as selection criteria in goat breeding programs.

\section{REFERENCES}

Andonov, S., J. Ødegård, I. A. Boman, M. Svendsen, I. J. Holme, T. Ådnøy, V. Vukovic, and G. Klemetsdal. 2007. Validation of testday models for genetic evaluation of dairy goats in Norway. J. Dairy Sci. 90:4863-4871.

Animal Improvement Programs Laboratory. 2011. Trend in milk PTA by breed for goats. Accessed Nov. 14, 2011. http://aipl.arsusda. gov/eval/summary/goats.cfm.

Bagnicka, E., E. Wallin, M. Łukaszewicz, and T. Ádnøy. 2007. Heritability for reproduction traits in Polish and Norwegian populations of dairy goat. Small Rumin. Res. 68:256-262.

Barillet, F. 2007. Genetic improvement for dairy production in sheep and goats. Small Rumin. Res. 70:60-75.

Bélichon, S., E. Manfredi, and A. Piacère. 1999. Genetic parameters of dairy traits in the Alpine and Saanen goat breeds. Genet. Sel. Evol. 31:529-534.

Boichard, D., N. Bouloc, G. Ricordeau, A. Piacere, and F. Barillet. 1989. Genetic parameters for first lactation dairy traits in the Alpine and Saanen goat breeds. Genet. Sel. Evol. 21:205-215.

de Jager, D., and B. W. Kennedy. 1987. Genetic parameters of milk yield and composition and their relationships with alternative breeding goals. J. Dairy Sci. 70:1258-1266.

Galina, M. A., E. Silva, R. Morales, and B. Lopez. 1995. Reproductive performance of Mexican dairy goats under various management systems. Small Rumin. Res. 18:249-253.

Gilmour, A. R., B. J. Gogel, B. R. Cullis, and R. Thompson. 2006. ASReml User Guide. Release 2.0. VSN International Ltd., Hemel Hempstead, UK.

Grossman, M., and G. R. Wiggans. 1980. Dairy goat lactation records and potential for buck evaluation. J. Dairy Sci. 63:1925-1937.

Guinee, T. P., E. O. Mulholland, J. Kelly, and D. J. O. Callaghan. 2007. Effect of protein-to-fat ratio of milk on the composition, manufacturing efficiency, and yield of Cheddar cheese. J. Dairy Sci. 90:110-123.

Haenlein, G. F. W. 1981. Dairy goat industry of the United States. J. Dairy Sci. 64:1288-1304.

Haenlein, G. F. W. 1996. Status and prospects of the dairy goat industry in the United States. J. Anim. Sci. 74:1173-1181.

Ilahi, H., P. Chastin, J. Martin, F. Monod, and E. Manfredi. 1998. Genetic association between milking speed and milk production. Pages 216-219 in Proc. 6th World Congr. Genet. Appl. Livest. Prod., Armidale, Australia. Vol. 24. University of New England, Armidale, NSW, Australia.

Iloeje, M. U., L. D. Van Vleck, and G. R. Wiggans. 1981. Components of variance for milk and fat yields in dairy goats. J. Dairy Sci. 64:2290-2293.

Jenness, R. 1980. Composition and characteristics of goat milk: Review 1968-1979. J. Dairy Sci. 63:1605-1630.

Kennedy, B. W., C. M. Finley, and G. E. Bradford. 1982. Phenotypic and genetic relationships between reproduction and milk production in dairy goats. J. Dairy Sci. 65:2373-2383.

Maga, E. A., P. Daftari, D. Kültz, and M. C. T. Penedo. 2009. Prevalence of $\alpha_{\mathrm{s} 1}$-casein genotypes in American dairy goats. J. Anim. Sci. 87:3464-3469.

Majid, A. M., T. C. Cartwright, J. A. Yazman, and H. A. Fitzhugh Jr. 1993. Performance of five breeds of dairy goats in southern United
States. I. Reproductive traits and maturing pattern. World Rev. Anim. Prod. 28:15-23.

Majid, A. M., T. C. Cartwright, J. A. Yazman, and H. A. Fitzhugh Jr. 1994. Performance of five breeds of dairy goats in southern United States. II. Lactation yield and curves. World Rev. Anim. Prod. 29:29-37.

Meinert, T. R., S. Korver, and J. A. M. Van Arendonk. 1989. Parameter estimation of milk yield and composition for 305 days and peak production. J. Dairy Sci. 72:1534-1539.

Montaldo, H., A. Juárez, J. M. Berruecos, and F. Sánchez. 1995. Performance of local goats and their backcrosses with several breeds in Mexico. Small Rumin. Res. 16:97-105.

Montaldo, H. H., and E. Manfredi. 2002. Organisation of selection programmes for dairy goats. Commun. No. 01-35 in Proc. 7th World Congr. Genet. Appl. Livest. Prod., Montpellier, France. Institut National de la Recherche Agronomique (INRA), Paris, France.

Montaldo, H. H., G. Tapia, and A. Juárez. 1981. Algunos factores genéticos y ambientales que influyen sobre la producción de leche y el intervalo entre partos en cabras. Técnica Pecuaria en México 41:32-44.

Montaldo, H. H., G. Torres-Hernández, and M. Valencia-Posadas. 2010a. Goat breeding research in Mexico. Small Rumin. Res. 89:155-163.

Montaldo, H. H., M. Valencia-Posadas, G. R. Wiggans, L. Shepard, and J. A. Torres-Vázquez. 2010b. Short communication: Genetic and environmental relationships between milk yield and kidding interval in dairy goats. J. Dairy Sci. 93:370-372.

Morris, C. A., M. Wheeler, and M. Lanuzel. 2006. Genetic trend and parameter estimates for milk yield traits and kidding date in a Saanen goat herd in New Zealand. N. Z. J. Agric. Res. 49:175-181.

Muller, C. J. C., S. W. P. Cloet, and S. J. Schoeman. 2002. Estimation of genetic parameters for milk yield and milk composition of South African Saanen goats. Commun. No. 01-52 in Proc. 7th World Congr. Genet. Appl. Livest. Prod., Montpellier, France. Institut National de la Recherche Agronomique (INRA), Paris, France.

Pizzillo, M., S. Claps, G. F. Cifuni, V. Fedele, and R. Rubino. 1994. Effect of goat breed on the sensory, chemical and nutritional characteristics of ricotta cheese. Livest. Prod. Sci. 94:33-40.

Raynal-Ljutovac, K., G. Lagriffoul, P. Paccard, I. Guillet, and Y. Chilliard. 2008. Composition of goat and sheep milk products: An update. Small Rumin. Res. 79:57-72.

Ruiz-Sánchez, R., R. W. Blake, H. M. A. Castro-Gámez, F. Sánchez, H. H. Montaldo, and H. Castillo-Juárez. 2007. Short communication: Changes in the association between milk yield and age at first calving in Holstein cows with herd environment level for milk yield. J. Dairy Sci. 90:4830-4834

Rupp, R., V. Clément, A. Piacere, C. Robert-Granié, and E. Manfredi. 2011. Genetic parameters for milk somatic cell score and relationship with production and udder type traits in dairy Alpine and Saanen primiparous goats. J. Dairy Sci. 94:3629-3634.

Serradilla, J. M. 2001. Use of high yielding goat breeds for milk production. Livest. Prod. Sci. 71:59-73.

Shanks, R. D., P. J. Berger, A. E. Freeman, and F. N. Dickinson. 1982. Genetic and phenotypic relations of milk production and postpartum length with health and lactation curve traits by lactation. J. Dairy Sci. 65:1612-1623.

Shrestha, J. N. B. 2005. Conserving domestic animal diversity among composite populations. Small Rumin. Res. 56:3-20.

Silva, E., M. A. Galina, J. M. Palma, and J. Valencia. 1998. Reproductive performance of Alpine dairy goats in a semi-arid environment of Mexico under a continuous breeding system. Small Rumin. Res. 27:79-84.

Soryal, K., F. A. Beyene, S. Zeng, B. Bah, and K. Tesfai. 2005. Effect of goat breed and milk composition on yield, sensory quality, fatty acid concentration of soft cheese during lactation. Small Rumin. Res. 58:275-281.

Swan, A. A., and B. P. Kinghorn. 1992. Evaluation and exploitation of crossbreeding in dairy cattle. J. Dairy Sci. 75:624-639.

Torres-Vázquez, J. A. 2008. Parámetros genéticos para características de producción y composición de la leche en cabras Saanen. MS 
Thesis. Facultad de Medicina Veterinaria y Zootecnia, Universidad Nacional Autónoma de México, México.

Torres-Vázquez, J. A., M. Valencia-Posadas, H. Castillo-Juárez, and H. H. Montaldo. 2009. Genetic and phenotypic parameters of milk yield, milk composition and age at first kidding in Saanen goats from Mexico. Livest. Sci. 126:147-153.

Torres-Vázquez, J. A., M. Valencia-Posadas, H. Castillo-Juárez, and H. H. Montaldo. 2010. Genetic and phenotypic trends for milk yield and milk composition traits of Saanen goats from Mexico. Revista Mexicana de Ciencias Pecurias 1:337-348.

Valencia, M., J. Dobler, and H. H. Montaldo. 2007. Genetic and phenotypic parameters for lactation traits in a flock of Saanen goats in Mexico. Small Rumin. Res. 68:318-322.

VanRaden, P. M., M. E. Tooker, J. B. Cole, G. R. Wiggans, and J. H. Megonigal Jr. 2007. Genetic evaluations for mixed-breed populations. J. Dairy Sci. 90:2434-2441.

Weppert, M., and J. F. Hayes. 2004. Direct genetic and maternal genetic influences on first lactation production in four breeds of dairy goats. Small Rumin. Res. 52:173-178.
Wiggans, G. R. 1984. Adjustment factors for milk records. Extension Goat Handbook, Fact Sheet D-4. Extension Service, US Department of Agriculture, Washington, DC.

Wiggans, G. R. 1989. Animal model evaluation of dairy goats for milk, fat, and protein yields with crossbred animals included. J. Dairy Sci. $72: 2411-2416$

Wiggans, G. R., and S. M. Hubbard. 2001. Genetic evaluation of yield and type traits of dairy goats in the United States. J. Dairy Sci. 84(E. Suppl.):E69-E73.

Wiggans, G. R., J. W. J. Van Dijk, and I. Misztal. 1988. Genetic evaluation of dairy goats for milk and fat yield with an animal model. J. Dairy Sci. 71:1330-1337.

Zeng, S. S., K. Soryal, B. Fekadu, B. Bah, and T. Popham. 2007. Predictive formulae for goat cheese yield based on milk composition. Small Rumin. Res. 69:180-186. 